\title{
A Brief View of the ESP Approach ${ }^{1}$
}

\section{Luis Guillermo Barrantes Montero}

Universidad Nacional, Costa Rica

\section{RESUMEN}

El artículo trata sobre el enfoque de Inglés para fines específicos. Está dirigido a profesores de Inglés general, aunque intenta también que la comunidad universitaria reconozca la importancia de evaluar la inversión de recursos en la enseñanza del Inglés en función de sus resultados concretados. Se of rece una descripción de las condiciones que se requieren para diseñar y efectuar estos cursos, acompañada de comentarios surgidos a partir de la experiencia del autor.

\section{Abstract}

This article provides information about the English for Specific Purposes (ESP) Approach. Although it is intended for teachers of General English, it also aims for the university community as a whole to evaluate how resources are currently invested in English teaching, with regard to the results obtained. A description of the conditions required to design and implement those courses is presented, along with the author's comments based on his own experience.

Palabras clave: Lingüística aplicada, enseñanza de idiomas, Inglés comercial Keywords: Applied Linguistics, language teaching, Business English

Received: 12 de setiembre 2008; accepted: 29 de julio de 2009.

2 E-mail: luisba66@yahoo.es 
"Tell me the need you have and I will tell you the language you need." (A principle of ESP)

\section{Introduction}

Nowadays, it is not unusual for companies to complain about their personnel's level of English. Job interviews and language test results are frequently insufficient to certify the suitability of a candidate for a given job position. Unfortunately, many people are hired under those conditions. However, problems come up right after they start working. They do not achieve very well when carrying out very specific tasks requiring language accuracy. Asking them to take more and more General English (GE) courses does not seem to make much difference. They need to be trained to use exactly the kind of language necessary for their tasks at work. That is what ESP is about.

ESP (English for Specific Purposes) can be considered to be an approach to language learning. ${ }^{3}$ It started in the 1960 s as a result of developments in Linguistics and in Educational Psychology, and is based on designing courses to meet specific learners' needs. Each course is preceded by a needs analysis which makes it unique; nevertheless, it is possible to establish characteristics that are common to all ESP courses. Dudley-Evans and St. John distinguish between absolute and variable characteristics:

3 Tony Dudley-Evans and Maggie St. John, in Developments in ESP (Cambridge: Cambridge University Press, 1998) 2, follow Hutchinson and Waters (1987) for whom "ESP is an approach rather than a product." That means that "ESP does not involve a particular kind of language, teaching material or methodology." In other words, "the foundation of ESP is the simple question: Why does this person need to learn a foreign language?" 


\section{Absolute Characteristics}

- ESP is designed to meet specific needs of the learner.

- ESP makes use of underlying methodology and activities of the disciplines it serves.

- ESP is centered on the language (grammar, lexis, register), skills, discourse and genres appropriate to these activities.

\section{Variable Characteristics}

- ESP may be related to or designed for specific disciplines.

- ESP may use, in specific teaching situations, a different methodology from that of general English.

- ESP is likely to be designed for adult learners, either for a tertiary institution or in a professional work situation. It could, however, be used for learners at secondary school level.

- ESP is generally designed for intermediate or advanced students. Most ESP courses assume basic knowledge of the language system, but it can be used with beginners." 4

These characteristics are very helpful for GE teachers concerned about the importance of ESP in current world context. GE teachers can understand, as ESP practitioners do, that they need to change not only the method they use for in their classes, but their own rationale and convictions for teaching. Learners attending our courses are involved in a globalized world requiring an international language. At least for now that language is English. In addition, the labor force must be appropriately skilled to perform the tasks. A worker with a poor performance might be fired sooner or later. Certain companies could transfer operations to other countries as well, where workers prove to be more efficient. Therefore, the goals of English teaching

$4 \quad$ Dudley-Evans and St. John, 4-5. 
today are far from just providing people with partial proficiency in the target language. New types of employment, as well as other present and future opportunities, are among the reasons involved in changing our minds in this regard.

\section{What does an ESP course imply?}

\section{Language description}

What is meant by saying that ESP is an approach is the recognition that other approaches to language teaching also exist. ESP, however, is an eclectic one; it came about as one way of satisfying specific needs. The first need learners have is to communicate accurately and precisely. Therefore, ESP takes elements from other approaches as a basis for its own methods and techniques. All communication has a structural level, a functional level and a discourse level, ${ }^{5}$ so all of these aspects must be included when designing an ESP course.

a. At the structural level, substitution tables and structural syllabi are very common in ELT. In an ESP course, rather than explaining rules per se, substitution techniques can be used in a reinforcement exercise such as the following:

Directions: Fill the blanks in column B. Use the following words: dessert $243 \quad$ menu snack lunch 432

5 Tom Hutchinson and Alan Waters, English for Specific Purposes (Cambridge: Cambridge University Press, 2000) 37. 


\begin{tabular}{|c|c|}
\hline $\begin{array}{l}\text { A. The Restaurant: Asking } \\
\text { for the Bill }\end{array}$ & $\begin{array}{l}\text { B. Complete the following } \\
\text { dialogue: }\end{array}$ \\
\hline $\begin{array}{l}\text { Client: Waiter, can I have the } \\
\text { bill, please? }\end{array}$ & $\begin{array}{l}\text { Client: Waiter, can I have the } \\
\text {, please? }\end{array}$ \\
\hline $\begin{array}{l}\text { Waiter: Yes, sir (gives bill to } \\
\text { client). }\end{array}$ & $\begin{array}{l}\text { Waiter: Yes, sir (gives bill to } \\
\text { client). }\end{array}$ \\
\hline Client: What's this for? & Client: What's this for? \\
\hline Waiter: That's for the wine, sir. & $\begin{array}{l}\text { Waiter: That's for the } \\
\text { sir. }\end{array}$ \\
\hline Client: I see. & Client: I see. \\
\hline $\begin{array}{l}\text { Waiter: Would you like to sign } \\
\text { for it? }\end{array}$ & $\begin{array}{l}\text { Waiter: Would you like to sign } \\
\text { for it? }\end{array}$ \\
\hline Client: Yes, please. & Client: Yes, please. \\
\hline $\begin{array}{l}\text { Waiter: What's your room } \\
\text { number? }\end{array}$ & $\begin{array}{l}\text { Waiter: What's your room } \\
\text { number? }\end{array}$ \\
\hline Client: 227. & Client: \\
\hline $\begin{array}{l}\text { Waiter: I hope you have } \\
\text { enjoyed dinner. }\end{array}$ & $\begin{array}{l}\text { Waiter: I hope you have } \\
\text { enjoyed }\end{array}$ \\
\hline
\end{tabular}

b. At the functional/notional level, we go beyond structure, which is based on form; here, we are dealing with language in use. An ESP syllabus that includes functions could have topics such as the following: making hotel reservations, giving tour information, ordering a meal, and making complaints. An ESP-task based on functions could be designed by taking samples of real work episodes supplied by the students. There should be room for improvement in those samples. The teacher can identify the errors and/or mistakes students make and may provide input activities in which students can

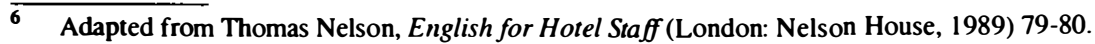


observe the correct form of what they have been doing wrong. Then, students are assigned a task in which they show acquisition.

c. At the discourse (rhetorical) level, the emphasis is on how meaning is generated between sentences. Meaning is much more than words in the sentence. The context has very much to do with meaning. For example, if we want to train learners to be efficient readers, we can design materials with which they can discover how sentences are combined in texts to create a particular meaning. This is another way of describing language that ESP should take into account, especially for designing materials. For example, students can be given a written text containing a dialogue between two business people. Then, they are given a card containing a task such as the following?:

Look at the text and mark where each of the following sections begins and ends:

1. Proposal made by one of the two people, regarding a new business.

2. Disagreement for investment conditions.

3. Final arrangements and conclusion.

\section{Models of learning and the affective factor}

There are as many learning styles as there are students in a class. A close relationship also exists between the teaching method chosen by the instructor and the feelings experienced by learners throughout the course. ESP practitioners and theorists recommend us to be friends of variety. The best teacher is not one who pleases everyone all the time, but one who tries to please most of the students most of the time. As an eclectic approach to learning, ESP courses may require,

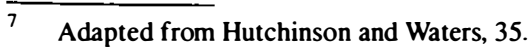


for example, a behaviorist technique to teach pronunciation, a cognitive technique to teach grammar and affective criteria to select texts. Teachers are empowered to feel free to take "what is useful from each theory" and trust the evidence of their own experience as teachers. $^{8}$

In an ESP course, the focus is neither on the teacher nor on the student, but rather on the learning situation, "because what we really want to discover is not the competence itself, but how someone acquires that competence." In other words, what Hutchinson and Waters mean is that the learning process is complex. The instructor, the students, the syllabus, the sponsors and the content are all factors of the learning process. They are very important, but they are only factors. ESP provides a way to make each factor accountable as well as complementary, and it is also a way to encourage students to become independent learners.

In addition to the models of learning, ESP practitioners should be aware of the affective factor. Motivation is crucial; nevertheless, we should not take for granted that our learners are very motivated just because of the target needs they have to meet if they want to keep their jobs. The teacher can increase motivation by bringing to class enjoyable, meaningful materials and attractive activities in which those materials may be used. Once instructors know the "likes" and "dislikes" of the people in their classes, those preferences will require more attention. However, this should be done keeping the essentials of the course in mind.

Gardner and MacIntyre define motivation as the "desire to achieve a goal, effort extended in this direction and satisfaction with the task." ${ }^{10}$ According to this definition, a successful ESP course is that in which the process of learning is an enjoyable experience. The

\footnotetext{
Hutchinson and Waters, 51 .

Hutchinson and Waters, 73.

R. C. Gardner and P. D. Macintyre, “A Student's Contributions to Second-language Learning. Part II: Affective variables." Language Teaching 26 (1993): 1-11.
} 
instructor has to facilitate that process. Moreover, the anxiety factor is a constraint for acquiring learning goals. It is a "stable personality trait referring to the propensity for an individual to react in a nervous manner when speaking ... in the second language." ${ }^{11}$ Despite personal situations the learner might be coping with, the ESP teacher can contribute a lot to reduce the feeling of anxiety. By defining the course essentials, there are many different ways for the instructor to help students who suffer anxiety. For example, the teacher does not need to force those learners to be absolutely correct in terms of syntax when the purpose of one activity is to convey a message. Another situation that can be a source of anxiety for certain students is when the boss of a group of workers is part of the class. The teacher needs to handle this situation very carefully, so that neither the boss nor the other students feel intimidated by the other's presence.

\section{The needs analysis}

The aim of an ESP course is to move learners from A (current performance) to B (target performance). It is not possible to design and develop an ESP course without previously conducting a needs analysis. It consists of a procedure or series of procedures intended to obtain information about both current performance and target performance. Rather than rules "written in stone," a needs analysis is an ongoing process. This means that needs detected before the course might change during the course and the teacher has to take note of those changes. In general, designing a needs analysis requires completing the following process:

1. Decide what information to gather and why.

2. Decide when, from whom and how to gather it.

3. Gather the information.

1 Rosamund Mitchell and Florence Myles, Second Language Leaning Theories (London: Amold, 2001) 19. 
4. Interpret it.

5. Act on it.

6. Evaluate the effects of the action. ${ }^{12}$

This process for gathering information has three stages:

1. Pre-course: Before the course begins, it is important to determine the students' level and the program's level, as well as target needs, students' interests and activities to be used.

2. Initial: During the first week, or weeks, of the course, information that could not be obtained in the pre-course stage, can still be gathered.

3. Ongoing: This stage takes place throughout the course and has the advantage of showing what changes should be made as the course progresses. ${ }^{13}$

Needs can be classified as follows:

- Necessities: what the learner should be able to do effectively in the target situation. It deals with the language a learner is required to master in order to function effectively in a certain situation.

- Lacks: the gap between target proficiency and present performance. In other words, the ESP practitioner should determine what the learner already knows in order to see whether the learner requires instruction in performing a given task.

- Wants: what the learners want or feel they need. ${ }^{14}$ This does not necessarily coincide with the information collected by the ESP practitioner regarding necessities and lacks. Other factors such as sponsors or institutional demands must also be taken into account.

12 Kathleen Graves, Designing Language Courses (Boston, Heinle and Heinle Publishers, 2000) 97.

13 Graves, 110.

14 Hutchinson and Waters, 55-56. 
During the pre-course stage of NA, it is important to design a personal profile chart for each student. The following is an example:

\section{The Student's Profile}

\section{Sample Profile}

This is sample of a student profile for an ESP course addressed to hotel staff in the area of Alajuela, Costa Rica.

Student's picture

Personal INFORMATION

\begin{tabular}{|l|l|}
\hline Name & María Vargas Carvajal \\
\hline Age range & $20-30$ \\
\hline Position & Receptionist \\
\hline Work place & Hotel Las Palmas \\
\hline Has worked there for & Six months \\
\hline Phone number & 22855660 \\
\hline E-mail & Mavacar@ hotmail.com \\
\hline English background & $\begin{array}{l}\text { 2-year English instruction at INA, } \\
\text { Naranjo. }\end{array}$ \\
\hline Weakest skill & Listening comprehension \\
\hline $\begin{array}{l}\text { Work tasks requiring } \\
\text { English }\end{array}$ & $\begin{array}{l}\text { a. Answering the phone } \\
\text { b. Attending the public }\end{array}$ \\
\hline Expectations & $\begin{array}{l}\text { Understand oral English and improve } \\
\text { pronunciation }\end{array}$ \\
\hline Learning style & $\begin{array}{l}\text { Group or pair work, note-taking and } \\
\text { revision }\end{array}$ \\
\hline
\end{tabular}


SPECIFIC NEEDS DETECTED IN DIAGNOSTIC TESTS

\begin{tabular}{|c|c|c|c|}
\hline Listening & Speaking & Reading & Writing \\
\hline $\begin{array}{l}\text { Understanding } \\
\text { specific data } \\
\text { such as names, } \\
\text { numbers, dates }\end{array}$ & $\begin{array}{l}\text { Improving } \\
\text { pronunciation } \\
\text { /th/ sounds and } \\
\text { other } \\
\text { consonants }\end{array}$ & $\begin{array}{l}\text { Basic } \\
\text { vocabulary to } \\
\text { sort mail }\end{array}$ & $\begin{array}{l}\text { Vocabulary and } \\
\text { format for } \\
\text { e-mail messages }\end{array}$ \\
\hline
\end{tabular}

RESULTS OF DIAGNOSTIC TESTS

\begin{tabular}{|c|c|c|c|c|}
\hline $\begin{array}{c}\text { Listening } \\
30 \%\end{array}$ & $\begin{array}{c}\text { Speaking } \\
30 \%\end{array}$ & $\begin{array}{c}\text { Reading } \\
20 \%\end{array}$ & $\begin{array}{c}\text { Writing } \\
20 \%\end{array}$ & $\begin{array}{c}\text { Proficiency } \\
\text { evel: } 73 \text { out } \\
\text { of } 100 \text { pts. }\end{array}$ \\
\hline 50 pts. $=15 \%$ & 70 pts. $=21 \%$ & 80 pts. $=16 \%$ & 70 pts. $=21 \%$ & High beginner \\
\hline
\end{tabular}

Although this student profile was developed during the precourse stage, some information can only be gathered in the initial stage.

\section{Goals and Objectives}

Information gathered by a needs analysis could be overwhelming and it will definitely be impossible to meet all the needs. What ESP specialists recommend is to define the scope of the course seriously but realistically. The best way to do that is by defining goals and objectives. ESP teachers should go to the absolute essentials, in terms of time, resources and course sponsors' demands. The following are definitions of goals and objectives, given by Brown ${ }^{15}$ :

15 J. D. Brown, The Elements of Language Curriculum (London: Heinle and Heinle, 1995) 71-72. 
a. Goals: "Statements concerning desirable and attainable program purposes and aims based on perceived language and situation needs."

b. Objectives: "Specific descriptions of the kind of learning behaviors the program will address."

GE teachers are probably more familiar with the terms General objective and Specific objectives. However, regarding goals and objectives, it would be difficult for many instructors to write them out or even distinguish a goal from an objective. Brown provides the following examples:

1. Understand conversational English.

2. Correctly understand sentences that function as examples within 600 -word passages of $11^{\text {th }}$ grade reading level on general science topics three out of four times.

3. Develop oral language skills that will prepare them to participate in class discussions, make oral presentations before an audience, and respond to questions, while continuing to improve through self-evaluated speech.

4. Find and write down the library call numbers for 10 books found in the card catalog when supplied with only the author and title, with $90 \%$ accuracy. ${ }^{16}$

According to the definitions given by the author, numbers 1 and 3 are goals, whereas 2 and 4 are objectives. Instructors need to focus on what they expect to achieve in the course as a whole and in every specific procedure in order to figure out the best way to set goals and objectives.

16 Brown, 75. 


\section{Course design}

Course design is the process of interpreting the raw needs analysis data to produce "an integrated series of learning experiences to lead learners to a particular state of knowledge. ${ }^{17}$ " Course design is intended to define an efficient and effective route for taking leamers from their current state of performance to a desirable state of performance. The following are some of the parameters, suggested by Dudley-Evans and St. John, which ESP teachers should consider before beginning the course design process:

1. Should the course be intensive or extensive?

2. Should the learner's performance be assessed or non-assessed?

3. Should the course deal with immediate needs or with delayed needs?

4. Should the role of the teacher be that of the provider of knowledge and activities, or of a facilitator of activities arising from learners' expressed wants?

5. Should the course have a broad or narrow focus?

6. Should the course be pre-study or pre-experience or run parallel with that study or experience?

7. Should the material be common-core or specific to leamers' study or work?

8. Should the group taking the course be homogeneous or heterogeneous?

9. Should the course design be worked out by the language teacher after consultation with the learners and the institution, or should it be subject to a process of negotiation with the learners? ${ }^{18}$

17 Hutchinson and Waters, 65.

18 Dudley-Evans and St. John, 145-146. 
We need to take into account that an ESP course will probably not be intensive, since it will take only one part of learner's timetable. Most students work or are regular students who can devote only a couple of hours twice a week; therefore, it is important to take advantage of the time and make each lesson have real value for learning. In some cases, learners will have their sponsor's permission tor an intensive course, in which each lesson requires a variety of activities as well as content reinforcement, so that students can show gradual improvement.

In ESP, what really counts for course sponsors is to see results; that means that perhaps standardized tests will not be required. Nevertheless, the teacher must establish parameters to measure each student's individual progress. When students are assigned a task, for example, the instructor needs an appropriate means by which that performance could be monitored. This will also give the teacher ideas about what features to review later and what features will not require extra instruction or practice.

Immediate or delayed needs were mostly revealed by NA; however, like everything in ESP, they could change. Course design has to be carried out flexibly enough so that one change in needs will not lead to the disruption of the entire plan.

The instructor's role, in general terms, is assumed to be that of a facilitator. This is especially true if we remember that ESP students ideally are supposed to have an acceptable level in GE. In some cases, though, students need basic instruction, and the course will not be successful if the teacher does not provide that instruction. That would be very time consuming. It would be a matter of negotiation with students and sponsors, in order to know whether all of them are willing to accept the time allotted to the program.

In addition, the instructor's role includes providing the language for students to perform efficiently and accurately in English. Subject matter is up to the students who must provide the raw material upon which the learning situation is built. Instructors are not required to be 
experts in any subject for teaching an ESP course related to any discipline. English teachers should not be held responsible for the entire weight of a course; they should provide a learning environment in which instructors and students can construct knowledge together. This idea is especially attractive for GE teachers who are afraid of ESP because they can not imagine themselves teaching a course on a subject with which they are not familiar.

Course breadth depends on many factors, of which the most significant are time and sponsors. In that case, the teacher must have plenty of possibilities for activities throughout the course, although some of them might not be possible to carry out. A pre-study or preexperience ESP course is intended to train students with the language skills they require in order to succeed in their studies or in a job position they have not started yet. A parallel ESP course is that pursuing the same objectives but while that study or job experience is in progress. In both cases, samples of real situations that learners will have to face or are facing should be available for teachers to decide on content and prepare the lessons. Specific materials are more appropriate for a parallel ESP course. The reason is that pre-experience students do not know much about the subject matter in which they will be immersed. In this case, "The ESP course will need to focus on the underlying competence needed, general EAP or EOP skills and language."

Whether the course is homogeneous or not is probably not the instructor's decision. Normally, group members are provided by sponsors. The teacher can do two things: ask sponsors to respect established criteria for selecting class members based on tests and needs analysis results; and then, find a common denominator among class members, once all possible modifications are made for the class to be as homogeneous as possible.

19 Dudley-Evans and St. John, 152; EAP is used to refer to English for Academic Purposes, and EOP refers to English for Occupational Purposes. For a broad explanation of ELT language subdivisions, see Hutchinson and Waters, 17. 
Finally, when a course is designed before having contact with learners, the planning should allow for flexibility. Needs analysis, goals and objectives are a good guide to trace the route of course design, but once direct contact starts in class, most of them may require significant modifications. If the course is designed after consulting the students, the instructor will have much more freedom and guidance for including what they need, like and expect.

All of the above considerations help course designers to be aware of the main factors to be taken into account. Even so, regardless of how carefully each step might be taken, at the time of starting the ESP course, the teacher needs to be ready to expect the unexpected. Many variables could modify the plans at the last moment. This challenging variability is precisely what makes ESP teaching the best way in which many teachers can fulfill their expectations to develop their talent.

Another consideration is that course design is also an ongoing process. Although we need to plan in advance, often several weeks before the course starts, that can cause many things to change, as Tessa Woodward has stated: "Thinking about our lessons and courses too far ahead and in too much detail, can be a waste of time. This is because things change once you get settled into the course."20

\section{Syllabus Design}

Once we have thought about course design, we must start exploring how to teach what we are supposed to teach. The answer to that question is that we need to prepare a syllabus. The idea of the syllabus is "to break down the mass of knowledge to be learnt into manageable units." 21 Certainly, a syllabus can be organized in many different ways. Therefore, in an ESP course we need specific criteria to organize the syllabus appropriately. Examples of possible types of syllabi for ESP courses are:

\footnotetext{
20 Tessa Woodward, Planning lessons and courses (Cambridge: Cambridge University Press 2001) 181 .

21 Hutchinson and Waters, 85
} 
- Topic syllabus:

1. the rig; 2. fishing jobs; 3. traps and geology, etc.

- Structural/situational syllabus:

1. The hotel staff (patterns of the verb 'to be'; demonstratives; personal pronouns); 2. The hotel staff (questions with where, prepositions); 3. Marcel in the restaurant (adjectives; 'either or', 'neither nor'); etc.

- Functional/notional syllabus:

1. Properties and shapes; 2. location; 3. structure; 4. measurements, etc.

- Skills syllabus:

1. Organizing your studies; 2. improving your reading efficiency;

3. taking notes; 4. taking part in seminars, etc. ${ }^{22}$

In all cases, the teacher will have to be eclectic, especially for pedagogic reasons, but also in order to keep the attention of learners and to show sponsors that what they are paying for is worthwhile.

\section{Materials Development}

It has already been stated that students and sponsors provide the subject matter for the course and the teacher provides the language training that students will require if they are to improve their proficiency. ESP instructors need to develop strategies to recycle their materials, because designing new materials constantly is expensive and time consuming. Specialists recommend three strategies:

a. Materials evaluation: re-using existing materials. Teachers need to compile and safeguard their materials, so they can use them in different courses.

22 Hutchinson and Waters, 85-87. 


\section{b. Materials adaptation: modifying and adapting materials to be used in different activities. Creativity could help teachers to use a certain exercise in different ways. \\ c. Materials development: creating new materials.}

Of course, when we develop materials, it is important to consider a balance between activities and exercises. According to Graves, "Too many exercises and too few activities will impede the ability to communicate in the real world." ${ }^{23}$ The most economical strategy is materials evaluation. "You may well be surprised how little of the course will really need new materials." 24

\section{Methodology}

A teacher coming to ESP from teaching GE might think that a totally new methodology would be necessary for these courses. Actually that is not true; the methodology is the quite similar. The learning-centered approach is what makes the difference. The instructor needs to be creative enough to develop class activities following the methodology he knows, but focusing on the aims of the ESP course. Instructors will definitely feel committed to learning along with the students. The instructors know about language, but they will need to learn about the subject matter. "A strength of ESP methodology is the way in which language learning and subject learning approaches can be integrated." 25

\section{Evaluation}

In part 5, the second topic to be considered for course design is whether the learner's performance should be assessed. Reasons for assessment are "for feedback to aid learning and for a comparable

\footnotetext{
23 Graves, 151.

24 Hutchinson and Waters, 126.

25 Dudley-Evans and St. John, 192.
} 
measure of competence." 26 An ESP course should be an enjoyable experience, and therefore, the anxiety level should be reduced. Many students cannot concentrate or feel comfortable during class activities due to panic when faced with evaluations. Instructors may design mechanisms to monitor and measure their students' progress in many different ways that prevent that constraint. As everything in ESP, assessment is a matter of decision-making and purpose. "Its real meaning (that of a grade) lies in understanding the reasons why it was given and what it tells the students about how they might improve their future work."27

\section{Conclusion}

The title of this article implies that there is much more to say about ESP than that stated here. Nevertheless, the idea of sharing these concepts, the theory and experiences is to motivate GE teachers to become more familiar with this teaching approach. Right after its presentation during CILAP, in October 2007, some teachers who work near tourist areas in Costa Rica expressed their interest in knowing more about it. As they said, many people are losing job opportunities just because their English is poor. And no matter how much time they spend studying regular English courses, they do not seem to improve. It is hoped that this presentation will help those workers to have a better command of English.

\footnotetext{
$\overline{26}$ Dudley-Evans and St. John, 210.

27 Hutchinson and Waters, 151.
} 